Review

\title{
The Role of Massage in Bereavement: A Scoping Review
}

Sarah Fogarty ${ }^{1, *}{ }^{+}$, Phillipa Hay ${ }^{2,+}$

1. Adjunct Fellow, School of Medicine, Western Sydney University, Locked Bag 1797, Penrith, NSW, Australia; E-Mail: s.fogarty@westernsydney.edu.au

2. Chair of Mental Health, School of Medicine, Western Sydney University, Locked Bag 1797, Penrith, NSW, Australia; E-Mail: P.Hay@westernsydney.edu.au

† These authors contributed equally to this work.

* Correspondence: Sarah Fogarty; E-Mail: s.fogarty@westernsydney.edu.au

Academic Editor: Wing-Fai Yeung

Special Issue: Massage for Mental Health Problems

OBM Integrative and Complementary Medicine 2019, volume 4, issue 4

doi:10.21926/obm.icm.1904058
Received: August 06, 2019

Accepted: September 29, 2019

Published: October 08, 2019

\begin{abstract}
Background: Death is a universal human experience. The experience of grief is unique for each person experiencing it. There is emerging research on modalities that provide support for bereaved individuals including bereavement massage. There is limited information in the literature about the specific role that massage can play in supporting bereaved individuals. The aim of this scoping review is to explore the literature that reports on the use and outcomes of bereavement massage so that massage therapists, consumers (the bereaved) and other health care professionals have a clearer idea about what bereavement massage is and how it may (or may not) be beneficial.
\end{abstract}

Methods: A scoping review methodology was used.

Findings: Whilst few, the articles identified were useful in describing bereavement massage use, putative outcomes and hypothesis generation. Bereavement massage techniques commonly used involve light pressure with treatment involving more than physical act of massage. Outcomes may be in improved somatic, physiological and/or emotional status.

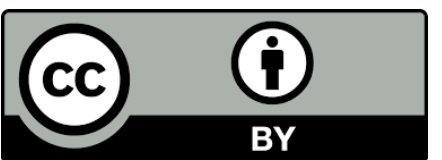

(C) 2019 by the author. This is an open access article distributed under the conditions of the Creative Commons by Attribution License, which permits unrestricted use, distribution, and reproduction in any medium or format, provided the original work is correctly cited. 
Summary: This review has highlighted the paucity of research in all aspects, understanding mechanisms and testing efficacy of massage for people who are bereaved. Further research on the role of massage in bereavement, potential efficacy and long and short-term outcomes is needed.

\section{Keywords}

Massage; bereavement; grief

\section{Introduction}

Death is a universal human experience and can be unexpected or expected after illness or injury. Bereavement is the "period of grief and mourning after a death" [1] and despite the varying configurations of the causes of death, grief touches all those who experience the death of someone they love. The experience of grief is unique for each person experiencing it but there are some common features of grief including somatic, physiological and psychological aspects. Somatic aspects of grief can include muscle tightness/muscle tension, body aching, headache, pain which can manifest differently in nature e.g. dull, aching, stinging, sharp, feeling of pressure, indeterminate pain (generalised or specific), physical weakness or restlessness [2-4]. Physiological manifestations of grief can include gut dysregulation, nausea, immune suppression, decreased appetite (and weight loss), increased appetite (and weight gain), difficulty breathing (dyspnoea), palpitations and extreme fatigue [2-6]. Common psychological manifestations of grief include sadness, crying, anxiety, difficulty sleeping (insomnia), flat affect/mood, feelings of abandonment and loneliness, confusion, disorientation, feelings of distress, isolation, depression, panic attacks, agitation, emotional exhaustion or anger $[2,5,6]$. The most common supportive tool that bereaved individuals seek is psychological support such as counselling, psychology or support groups [7]. There is emerging research on other modalities that provide support such as exercise and complementary medicine [8-11].

Bereavement massage, according to Weber (2018), is 'a distinct massage method that combines various modalities to address grief' [12]. There is no consensus on the definition of the term bereavement massage and it has been used in the context of palliative massage treatments or end-of-life support $[2,12]$. For the purpose of this paper bereavement massage is defined as the application of massage therapy to assist with the manifestations of bereavement. There is limited information in the literature about the specific role that massage can play in supporting bereaved individuals including massage techniques, the purpose of the treatment, the role of the therapist and additional skills required to undertake this type of massage. Scoping reviews are used specifically in areas which have not been reviewed comprehensively before to summarise and disseminate existing literature findings and to identify gaps in the evidence base where no research has been conducted [13]. While scoping reviews are popular in the area of bereavement itself [14-16] bereavement massage has not been reviewed. Given the limited research conducted on bereavement massage and that a review in this area has not occurred before, a scoping review methodology is well suited to explore the literature that reports on the use and outcomes of bereavement massage so that massage therapists, consumers (the bereaved) and other health 
care professionals have a clearer idea about what bereavement massage is and how it may (or may not) be beneficial.

\section{Materials and Methods}

A scoping review methodology provides the opportunity to summarise a wide range of literature to map key concepts and gaps in the research [13]. A preliminary review of the literature reporting on bereavement massage suggested a scoping review methodology was appropriate as there was very limited primary research. The aim of this scoping review is to summarise and disseminate the literature findings and to identify research gaps in the existing literature [13].

The scoping methodology used in this review was the five-stage process as outlined by Arksey and O'Malley (2005) [13] and further developed by Levac, Colquhoun and O'Brien (2010) [17]. The steps included are: (1) to identify the research question; (2) to identify relevant studies; (3) study selection; (4) charting the data; and (5) collate, summarize and report results [13].

\subsection{Stage 1: Identifying the Research Question}

The aim of this review was to summarise and disseminate the literature findings and to identify research gaps in the existing literature by asking the following questions about bereavement massage: what is known about bereavement massage practice? What evidence is there to support bereavement massage? The scoping review will identify the literature on bereavement massage to determine what is known about bereavement massage practice, which will inform clinical practice and education and to determine the evidence to support bereavement massage and guide future research in this area.

\subsection{Stage 2: Identifying Relevant Studies}

\subsubsection{Intervention}

The intervention is massage therapy, which is defined as "a patterned and purposeful softtissue manipulation accomplished by use of digits, hands, forearms, elbows, knees and/or feet, with or without the use of emollients, liniments, heat and cold, hand-held tools or other external apparatus, for the intent of therapeutic change [18]." Massage therapies include Swedish massage, aromatherapy massage, hot stone massage, myotherapy, deep tissue massage, sports massage and remedial massage.

Inclusion. The intervention i.e. massage therapy, must be applied by a qualified massage therapist or other health care professional such as a nurse.

Exclusion. Palliative or end-of-life massage or massage to support family members of those dying were excluded from the review. Touch therapy was also excluded.

\subsubsection{Population}

The study population was bereaved individuals. 


\subsubsection{Literature Inclusion}

Inclusion. The study designs considered for inclusion in the review included qualitative and quantitative studies that reports on the use (such as how it is used and why it is used) of or experience of bereavement massage and grey literature that reports on the use of or experience of bereavement massage. Eligibility was confined to English literature only with no date or publication limitations.

Exclusion. Individual practitioner websites that mention bereavement massage were excluded.

\subsubsection{Search Strategy}

A four-step search strategy was used. Step 1 included an initial limited search of CINAHL and Scopus using the words "bereavement" or "grief" and "massage" or "soft tissue" or "myotherapy" to identify keywords to use across all databases. The key words identified were "bereavement", "grief" and "massage".

Step 2 involved searching the following databases: PsycINFO via OVID, Pubmed, Medline (EBSCO), Scopus, PEDRO, Allied and Complementary Medicine Database (AMED), CINAHL, Cochrane Library (CENTRAL) and ProQuest Dissertations using the identified keywords.

Step 3 involved searching the internet using Google to identify any literature. The first three pages of the Google search results were included.

Step 4 involved searching the reference list of all identified literature for additional studies.

Publication Limitations. The search for relevant papers was from database inception until June 2019 and limited to those published in English. The Google search included the first three results pages only.

\subsection{Stage 3: Study Selection}

One reviewer (SF) independently screened all titles and abstracts for inclusion into the study. A second reviewer, $(\mathrm{PH})$, was available to consult regarding any cases of uncertainty regarding inclusion and to review the included studies to confirm eligibility.

\subsection{Stage 4: Charting the Data}

Data from the included articles will be extracted and will include the following key criteria including author, year of publication, study title, study location, purpose/aims of the study and significant findings/recommendations.

\subsection{Stage 5: Collating, Summarising and Reporting the Results}

We used a three-phase approach to collate, summarise and report the results [17]. This involved a descriptive numerical analysis including the number of articles, years of publication, and study types. An analysis of the included studies are reported including identifying what is known about bereavement massage including the strengths and weakness of the included studies. The third stage involved the implications of the findings in relation to clinical practice, future research and policy. 


\section{Findings}

The search was undertaken 20 June 2019 to 27 June 2019. The search identified 125 articles. One hundred and seventeen were excluded and with the 8 remaining articles the full text papers/literature were obtained and assessed for eligibility. There was no uncertainty about inclusion of the literature. See figure 1 for a flow chart of the literature search process.

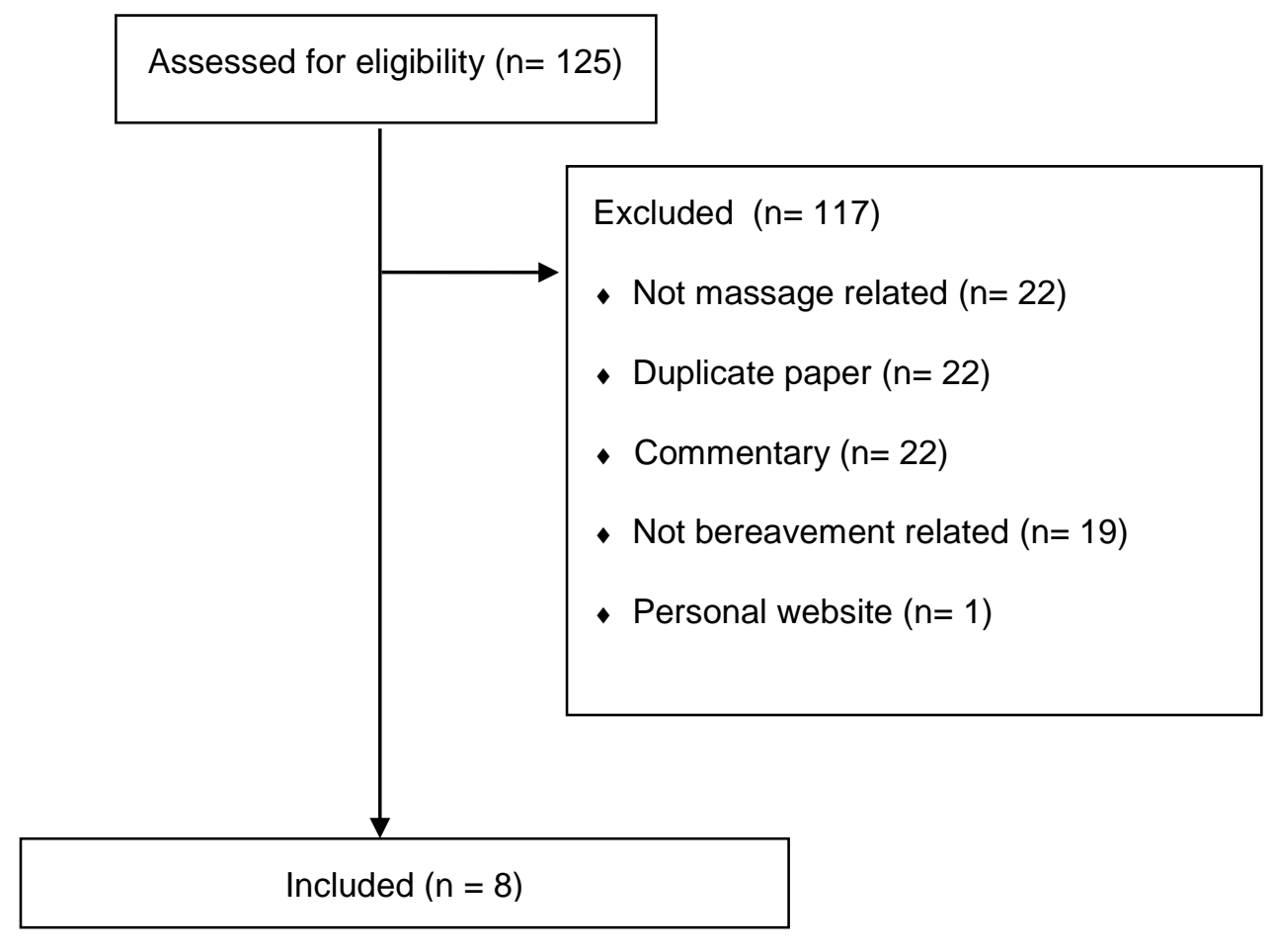

Figure 1 Flow Diagram of literature search.

\subsection{Descriptive Summary}

The review found eight articles from 2010 to 2019. There was one research article that was qualitative in methodology [4], one article was a grant application [19], three were three non referred periodical articles $[3,12,20]$ and three blogs were published either on grief massage education websites or massage association websites [2, 21, 22]. The publication dates cluster around 2010-2011 and 2017-2019. See Table 1. 
Table 1 Summary of data extracted from the articles.

\begin{tabular}{|c|c|c|c|c|c|}
\hline $\begin{array}{l}\text { Author and } \\
\text { year of } \\
\text { publication }\end{array}$ & Title & $\begin{array}{l}\text { Country } \\
\text { of origin }\end{array}$ & Type of article & Aims/purpose & Main Content of the literature \\
\hline $\begin{array}{l}\text { Cronfalk et } \\
\text { al } 2010[4]\end{array}$ & $\begin{array}{l}\text { Soft tissue } \\
\text { massage: early } \\
\text { intervention for } \\
\text { relatives whose } \\
\text { family members } \\
\text { died in palliative } \\
\text { cancer care }\end{array}$ & Sweden & $\begin{array}{l}\text { Referred } \\
\text { journal article }\end{array}$ & $\begin{array}{l}\text { Explore how } \\
\text { bereaved relative's } \\
\text { experienced early } \\
\text { intervention with } \\
\text { soft tissue massage } \\
\text { during the first } \\
\text { four months after } \\
\text { the death of a } \\
\text { family member. }\end{array}$ & $\begin{array}{l}\text { Sample Size: Eighteen relatives whose family members who } \\
\text { had died. } \\
\text { Research Method: Qualitative study using in-depth } \\
\text { interviews. } \\
\text { Intervention: Soft tissue massage ( } 25 \text { min hand or foot) } \\
\text { once a week for } 8 \text { weeks. } \\
\text { Main Findings: Soft tissue massage proved to be helpful and } \\
\text { to generate feelings of consolation. The main findings were: } \\
\text { (1) a helping hand at the right time, (2) something to rely } \\
\text { on, (3) moments of rest and (4) moments of retaining } \\
\text { energy. The categories were then conceptualised into this } \\
\text { theme: feelings of consolation and help in learning to } \\
\text { restructure everyday life. }\end{array}$ \\
\hline $\begin{array}{l}\text { Miller et al } \\
\text { [19] }\end{array}$ & $\begin{array}{l}\text { Using Massage as } \\
\text { a Coping } \\
\text { Mechanism for } \\
\text { the Grieving } \\
\text { Process Pre and } \\
\text { Post Death of a } \\
\text { Loved One }\end{array}$ & US & $\begin{array}{l}\text { Grant } \\
\text { Application }\end{array}$ & $\begin{array}{l}\text { Study on massage } \\
\text { and bereavement } \\
\text { for International } \\
\text { Academy of } \\
\text { Massage research } \\
\text { grant }\end{array}$ & $\begin{array}{l}\text { Grant application including a literature review, proposed } \\
\text { project, methodology and outcome measures }\end{array}$ \\
\hline $\begin{array}{l}\text { Moore } \\
2019[2]\end{array}$ & $\begin{array}{l}\text { What is } \\
\text { Bereavement }\end{array}$ & AUS & $\begin{array}{l}\text { Blog (on } \\
\text { massage }\end{array}$ & $\begin{array}{l}\text { To discuss what is } \\
\text { bereavement }\end{array}$ & $\begin{array}{l}\text { Presenting information on how grief affects the body both } \\
\text { physically and emotionally, how massage may help and the }\end{array}$ \\
\hline
\end{tabular}




\begin{tabular}{|c|c|c|c|c|c|}
\hline & Massage & & $\begin{array}{l}\text { association } \\
\text { website) }\end{array}$ & massage & purpose of the treatment of people with grief. \\
\hline $\begin{array}{l}\text { Rose } 2011 \\
{[3]}\end{array}$ & $\begin{array}{l}\text { Massage and } \\
\text { Body Work Grief } \\
\text { and loss }\end{array}$ & US & $\begin{array}{l}\text { Non referred } \\
\text { journal article }\end{array}$ & $\begin{array}{l}\text { Describing grief } \\
\text { and loss }\end{array}$ & $\begin{array}{l}\text { Presenting information predominately on grief and how the } \\
\text { body responds to grief. Talks about the cycles of grief and } \\
\text { the role of massage in these cycles. }\end{array}$ \\
\hline $\begin{array}{l}\text { Taylor } 2017 \\
\text { [20] }\end{array}$ & $\begin{array}{l}\text { Massage for the } \\
\text { grieving, where } \\
\text { love lived first }\end{array}$ & US & $\begin{array}{l}\text { Non referred } \\
\text { journal article }\end{array}$ & $\begin{array}{l}\text { Describing } \\
\text { massage for the } \\
\text { grieving }\end{array}$ & $\begin{array}{l}\text { An article covering a number of topics for bereavement } \\
\text { massage including her journey to bereavement massage, } \\
\text { the funded community project, techniques used in the } \\
\text { massage, how to apply the techniques, outcomes from the } \\
\text { massage technique, what the techniques are aiming to do } \\
\text { and scope of practice. }\end{array}$ \\
\hline $\begin{array}{l}\text { Taylor, } \\
2018[21]\end{array}$ & $\begin{array}{l}\text { The Grief } \\
\text { Massage, } \\
\text { Philosophy and } \\
\text { approach }\end{array}$ & US & $\begin{array}{l}\text { Blog (on grief } \\
\text { massage } \\
\text { institute } \\
\text { website) }\end{array}$ & $\begin{array}{l}\text { Discussing the } \\
\text { philosophy of grief } \\
\text { massage }\end{array}$ & $\begin{array}{l}\text { Presenting information on the philosophy behind the Grief } \\
\text { Massage approach. }\end{array}$ \\
\hline $\begin{array}{l}\text { Taylor, } \\
2019[22]\end{array}$ & $\begin{array}{l}\text { Communication } \\
\text { skills and grief } \\
\text { massage }\end{array}$ & US & $\begin{array}{l}\text { Blog (on grief } \\
\text { massage } \\
\text { institute } \\
\text { website) }\end{array}$ & $\begin{array}{l}\text { Discussing } \\
\text { communication } \\
\text { skills and grief } \\
\text { massage }\end{array}$ & $\begin{array}{l}\text { Presenting information on the role of communication skills } \\
\text { in bereavement massage. }\end{array}$ \\
\hline $\begin{array}{l}\text { Weber, } \\
2018[12]\end{array}$ & $\begin{array}{l}\text { Grief massage } \\
\text { therapy sessions } \\
\text { help clients cope }\end{array}$ & US & $\begin{array}{l}\text { Non referred } \\
\text { journal article }\end{array}$ & $\begin{array}{l}\text { To describe how } \\
\text { grief massage } \\
\text { helps clients cope }\end{array}$ & $\begin{array}{l}\text { An article with the creators of Bereavement Massage } \\
\text { Therapy approach including techniques used in the } \\
\text { massage, how to apply the techniques, outcomes from the } \\
\text { massage technique. }\end{array}$ \\
\hline
\end{tabular}




\subsection{Themes from the Data}

Data from the articles has been extracted and organised into themes. The themes are: 1) techniques used in bereavement massage, 2) how does bereavement massage work, 3) Qualitative outcomes of bereavement massage and 4) Defining professional bereavement massage boundaries.

\subsection{Techniques Used in Bereavement Massage}

There was no consensus on the techniques used in bereavement massage; however, relaxation/light pressure and safety were common features. There were two specific massage approaches developed by individuals; the Grief Massage [20] and the Bereavement massage [12]. These approaches are not standard massage approaches and they are not taught as part of standard massage therapy education. The aim of the Grief Massage approach $[20,21]$ is to not treat the body but aims to shift the client from a stressed state to a relaxation state. They perceive that light touch and making the client feel safe are the ways to achieve this. This approach uses "slow pacing and gentle pressure with techniques such as sweeping effleurage, static hand holds (allowing "soft hands" to rest on the client for 5-10 seconds), and nerve strokes which are helpful for areas such as the arms and back, while petrissage is utilized on the calves with very soft "squeezing" working well for the feet" [20]. This approach avoids treatment of the gluteal muscles, quadriceps, hamstrings and pectoral muscles as they feel that these areas can be sensitive [20, 21].

The Bereavement Massage approach requires three treat sessions according to the individual who developed it and uses "flat-hand vibration, gentle rocking and comfort holds to loosen and calm disconnected areas" [12]. This approach also incorporates such techniques from other complementary medicine modalities such as "reflexology, polarity and craniosacral techniques" [12]. In addition there is very little talking in the Bereavement Massage approach and the therapist needs to use the same sequence in each of the three treatment sessions [12].

\subsection{How Does Bereavement Massage Work?}

None of literature specifically mentions how bereavement massage works; however a number mention specific aspects of grief or bereavement that their massage is targeting. The Grief Massage approach assists with moving the client to a relaxed state by aiming to shift the "body from the flight-or-fight response to a relaxed, restorative state" and claims it has a restorative impact on the nervous system [20]. Taylor states that the Grief Massage approach provides "assisted relaxation" whereby the massage and the safe environment provide assistance to the client to slip out of the stress state for a while so that restoration can occur on a physical level [21]. Taylor also states that "massage is a unique way to help alleviate some of the physical discomforts associated with early bereavement [20]". The Bereavement Massage approach gives the client "a sense of balance during a time of upheaval" [12].

Interestingly, a number of articles mention that massage targets the side effects of grief, both physical and emotional and particularly combating the effects of stress [2-4, 20, 21]. These articles acknowledge that bereavement can be stressful and they cite both physical and psychological symptoms of stress $[2-4,20,21]$. Despite mentioning that bereavement can lead to physical symptoms such as indeterminate pain, headache, extreme fatigue, aching body with sore 
shoulders, painfully clenched jaw and or physical weakness or restlessness $[2,4,12,20]$ neither the Grief Massage nor the Bereavement Massage approach aims to address these physical symptoms specifically. In fact, in both cases, they specifically aim not to address pain issues or try to "fix" anything about the physical body such as releasing muscle tension, working out knots, or improving range of motion $[12,21]$.

Moore believes that bereavement massage works to 1) "facilitate the relaxation response, 2) promote a sense of physical wellbeing, 3) validate and normalise feelings and thoughts, 4) create and hold a calm, safe space for emotional expression and reflection, 5) provide grief education, 6) encourage self-agency and explore coping strategies and 6) monitor for referrable indicators [2].

\subsection{Qualitative Outcomes of Bereavement Massage}

Bereavement massage appears to be more than just a hands-on massage - Taylor describes a massage ecosystem for bereavement massage where all aspects of the consultation; the treatment, rapport, actions and environment contribute to the client feeling safe and understood [22]. This is reiterated by Moore who indicates that that the aims of the bereavement massage extend beyond the physical touch and include not only facilitating the relaxation response and promoting a sense of physical wellbeing but "validating and normalising feelings and thoughts, creating and holing a calm, safe space for emotional expression and reflection, providing grief education, encouraging self-agency and exploring coping strategies and monitoring for referrable indicators [2]. This is also reiterated by the 2010 qualitative study investigating soft tissue massage in the first four months after the death which found massage to be "a helping hand at the right time, something to rely on, moments of rest and moments of retaining energy" [4]. The final themes were feelings of consolation and help in learning to restructure everyday life [4].

The article on Bereavement Massage indicated that recipients of bereavement massage reported a "sense of feeling lighter" and states that the regularity of receiving the same massage routine provides comfort and solace to the client [12].

A massage therapist that provided massage in a couple of community Grief Massage programs felt that "Our clients often had a palpable sense of sadness, despair, and hopelessness when they entered into our program. While grief massage doesn't alleviate these symptoms, our clients generally left their sessions feeling more physically relaxed, less anxious, and less depressed" [20].

In terms of side effects of bereavement massage, Taylor's clinical experience is that "many grieving clients display increased sensitivity to pressure and seem especially prone to next-day soreness and there seems to be an increased potential for emotional release" [20].

The majority of articles purported that massage does not eliminate the grieving process or fix the grief $[2-4,12,19-23]$ and therefore these are not outcomes of bereavement massage.

\subsection{Defining Professional Bereavement Massage Boundaries}

Bereavement massage requires specific skills and boundaries that may differ from nonbereavement massage treatments. A number of the articles were clear that the massage therapists offering bereavement massage are "not a counsellor" and that massage therapists need to make sure they stick within their scope of practice and refer to a counsellor if required [12, 20, $22]$. None of the articles gave any advice or tips on avoiding taking on the role of the counsellor and keeping the professional boundaries in place. 
Communication skills were identified as being important by Taylor who believes that communication skills are extremely important when working with bereaved individuals and that being a skilled communicator can "genuinely and warmly help another person to feel safe and understood" [22]. Taylor spends quite a bit of time in her article defining the purpose of good communication skills ("to facilitate building a warm relationship (rapport) with clients so they feel safe and understood and can share important session-related information" [22]) rather than being intended as a form of counselling.

\section{Discussion}

There is very little known about bereavement massage practice and there is a paucity of evidence to support bereavement massage. There is limited information specifically about the techniques, aims, efficacy and outcomes of bereavement massage. The information available is mixed. The aims of bereavement massage overall appear to be to treat the somatic/body, psychological and or emotional aspects of health associated with grieving such as stress; and this appear to be mainly addressed by treating the physical manifestations of grief such as pain and also physiological manifestations such as the flight-or-fight response or increased sympathetic nervous system, in particular by encouraging the relaxation response $[2,20,21]$. However, a number of massage approaches specifically aimed not to address the physical manifestation's of grief and or stress such as aches and pains $[12,20]$. There was little explicit information about what clinical measures were being used to assess treatment efficacy, what exactly these approaches were treating and what constitutes a successful treatment.

It appears that there are two different types of bereavement massage treatment that have the potential to yield benefits for bereaved individuals; a moderate pressure massage treatment or a light pressure treatment and that the majority of information published on bereavement massage involves light pressure treatment. However, it is unclear what constitutes a light pressure and what constitutes a moderate pressure.

The potential benefits and mechanisms for a moderate pressure massage may include:

- An increase in parasympathetic activity as per the relaxation response which aims to counteract and be protective against the symptoms of increased sympathetic nervous systems activity e.g. flight or fight [24].

- Managing the psychological symptoms of grief via higher heart rate variability which is "related to attentional, emotional and behaviour self-regulation [25] and increased vagal activity which increases cerebral blood flow across several brain regions involved in depression and stress regulation $[26,27]$. This could be helpful in helping the grieving individual self-regulate emotion more effectively during times of stress [25] and help grieving individuals manage the symptoms of grief such as stress, anxiety and or depression. This may also have a protective mechanism for positive mental health [25].

- Pain reduction via the gate theory for pain reduction ("pain is carried more slowly by the less insulated $C$ neurons and massage signals are carried more rapidly by the $A$ neurons that close the gate to the C impulses") [27] or through increased serotonin levels ("serotonin being the body's natural anti-pain chemical") [27].

- Addressing and managing grief-related muscular tightness such as tight neck and shoulders and or headaches. 
A number of bereavement massage approaches in this review specify only light touch $[12,20]$. The potential benefits and mechanisms for a massage treatments using light or affective touch (tactile processing with a hedonic or motional component) may include:

- Evoking feelings of pleasure, reassurance, comfort and soothing by targeting different aspects of the brain such as the posterior insula and superior temporal sulcus [28].

- $\quad$ Decreasing pain via the motivation-decision model of pain [27].

For affective touch or light touch, this type of touch is affected by context and the person's internal motivational state or mood and their behavioural response [28]. The pleasantness of the touch in light massage treatments is therefore impacted by visual and auditory stimuli such as the smell of the treatment space, the emotions shown on the face of the massage therapist, the tone of the therapists voice and the words the therapist uses [28]. This may be a factor in the treatments utilising light touch and not involving the therapist talking.

As bereaved individuals may differ in the way in which grief manifests, people's needs from a massage might also differ. For individuals who experience their grief and stress more physically, e.g. tight muscles, pain or fatigue, then a moderate pressure massage targeting muscle tension might be clinically more appropriate. For individuals who experience their grief and stress emotionally, a moderate massage seeking changes in the parasympathetic system might be more clinically appropriate. For individuals who want to be reassured and soothed then a light touch massage might be more clinically appropriate. For individuals targeting grief-related pain then either a moderate or light massage could be clinically appropriate. The needs of the bereaved individual and how they manifest their grief and stress may fluctuate and or change over time and thus their massage treatment needs might vary from treatment to treatment and or over time.

It was clear that all the massage treatments involved in this review involved more than just the physical act of massage in bereavement massage treatments with communication, safety and education being important skills the therapists could apply to bereavement treatments $[2,12,20$, 21]. What literature was on outcome was either qualitatively based or was presented qualitatively. Given the complex nature of grief and that massage is more than just the treatment, a qualitative approach or a qualitative aspect to any research would be enable researchers to capture the effects of the therapist, the consultation and the massage in bereavement massage. In addition, there was almost no quantitative data presented in the literature and there is a large evidence gap about the role of massage to help individuals manage stress, depression, anxiety and cope with grief in the bereavement period.

Interestingly, while a number of publications mentioned treating safely $[2,3,20]$ not one publication mentioned the potential for bereaved individuals to have increased vulnerability. The importance of this is paramount as vulnerable individuals may not be able to communicate their needs as efficiently as non-bereaved individuals making miscommunication more likely to occur $[29,30]$. In addition, bereaved individuals may be more vulnerable to trauma (either emotionally, verbally or physically) and therapists need to be aware of their actions to limit any possible trauma [31].

There is a lack of understanding of how exactly massage effects reported occur; and the authors reported limited clinical observations. While massage was shown to consolidate and help in learning to restructure everyday life [4] more research evidence is needed to provide information on the role of massage in bereavement, potential efficacy and long and short term outcomes. 


\subsection{Strengths and Limitations}

While this review has allowed us to explore the use and outcomes of bereavement massage there are some limitations. There were very few sources of literature, and only one methodologically rigorous research paper identified, making the scoping study methodology well suited but not allowing for conclusions to be made. Further, only English language literature was included so relevant studies may have been missed. Literature was predominantly from the USA and thus might not be generalizable to other countries. A professional information specialist was not involved, and we cannot rule out that there is additional existing material that was not retrieved in our search.

\section{Summary}

This review has highlighted the paucity of research in all aspects, understanding mechanisms and testing efficacy of massage for people who are bereaved. Whilst few, the articles identified were useful in describing bereavement massage use, putative outcomes and gaps in the research. Bereavement massage techniques commonly used involve light pressure with treatment involving more than the physical act of massage. Outcomes may be in improved somatic, physiological and/or emotional status. Consumers are using bereavement massage and it appears to be an important resource for bereaved individuals to help manage their grief. Given the complexity of grief and the importance of the treatment consultation, both qualitative and quantitative research methods investigating the efficacy of bereavement massage is needed and a putative hypotheses to be investigated could be: massage reduces somatic and physiological effects during bereavement to a greater extent than an active control. There is also a gap in the research around increased vulnerability of bereaved individuals and their capacity to communicate effectively with health care providers and more research needed on how healthcare providers can improve their interactions with bereaved individuals so as not to add to their distress. Further research on the efficacy of different types of massage in bereavement, i.e. specific bereavement massage approaches versus more standard massage approaches, and long and short-term outcomes is needed and putative hypotheses to be investigated include: moderate massage reduces somatic and physiological effects during bereavement to a greater extent than light massage.

\section{Author Contributions}

Both authors contributed equally to the study conception and design, searching, analysis, drafting and revising.

\section{Funding}

None.

\section{Competing Interests}

Professor Phillipa Hay receives sessional fees and lecture fees from the Australian Medical Council, Therapeutic Guidelines publication, and New South Wales Institute of Psychiatry and royalties from Hogrefe and Huber, McGraw Hill Education, and Blackwell Scientific Publications 
and receives support from Shire Pharmaceuticals for speaking engagements. Dr Sarah Fogarty is a practicing massage therapist.

\section{References}

1. Collins Dictionary of the English Language. Sydney: Collins; 1979.

2. Moree R. AMT's Blog: AMT (Association of Massage Therapists). 2019. [cited 2019]. Available from: https://blog.amt.org.au/index.php/2019/02/27/what-is-bereavement-massage/.

3. Rose MK. Grief and loss. Providing a safe haven for clients. Massage and Bodywork [Internet]. $2011 \quad$ [cited $2019 \quad 17$ June]. Available from: https://www.abmp.com/textonlymags/article.php?article=129.

4. Cronfalk BS, Ternestedt BM, Strang P. Soft tissue massage: Early intervention for relatives whose family members died in palliative cancer care. J Clin Nurs. 2010; 19: 1040-1048.

5. Buckley T, Sunari D, Marshall A, Bartrop R, McKinley S, Tofler G. Physiological correlates of bereavement and the impact of bereavement interventions. Dialogues Clin Neuro. 2012; 14: 129-139.

6. Pohlkamp L, Kreicbergs U, Sveen J. Bereaved mothers' and fathers' prolonged grief and psychological health 1 to 5 years after loss-A nationwide study. Psycho-oncology. 2019; 28: 1530-1536.

7. Waller A, Turon H, Mansfield E, Clark K, Hobden B, Sanson-Fisher R. Assisting the bereaved: A systematic review of the evidence for grief counselling. Palliat Med. 2016; 30: 132-148.

8. Huberty J, Leiferman JA, Gold KJ, Rowedder L, Cacciatore J, McClain DB. Physical activity and depressive symptoms after stillbirth: Informing future interventions. BMC Pregnancy Childb. 2014; 14: 391.

9. Huberty JL, Matthews J, Leiferman J, Cacciatore J. Experiences of women who participated in a beta-test for an online-streamed yoga intervention after a stillbirth. Int J Yoga Ther. 2017; 27: 59-68.

10. Huberty JL, Matthews J, Leiferman J, Hermer J, Cacciatore J. When a baby dies: A systematic review of experimental interventions for women after stillbirth. Reprod Sci. 2017; 24: 967-975.

11. Huberty J, Matthews J, Leiferman JA, Lee C. Use of complementary approaches in pregnant women with a history of miscarriage. Complement Ther Med. 2018; 36: 1-5.

12. Weber P. Grief massage therapy sessions help clients cope. Massage Magazine [Internet]. 2018 [cited 201917 June]. Available from: https://www.massagemag.com/grief-massagetherapy-sessions-90041/.

13. Arksey H, O'Malley L. Scoping studies: Towards a methodological framework. Int J Soc Res Methodol. 2005; 8: 19-32.

14. Chen C, Chow AYM, Tang S. Professional caregivers' bereavement after patients' deaths: $A$ scoping review of quantitative studies. Death Dtud. 2019; 43: 500-508.

15. Wilson DM, Dhanji N, Playfair R, Nayak SS, Puplampu GL, Macleod R. A scoping review of bereavement service outcomes. Palliat Support Care. 2017; 15: 242-259.

16. Thornton R, Nicholson $P$, Harms L. Scoping review of memory making in bereavement care for parents after the death of a newborn. Jognn-J Obst Gyn Neo. 2019; 48: 351-360.

17. Levac D, Colquhoun H, O'Brien K. Scoping studies: Advancing the methodology. Implement Sci. 2010; 5 . 
18. Kennedy A, Cambron J, Sharpe P, Travillian R, Saunders R. Clarifying definitions for the massage therapy profession: The results of the best practices symposium. Int J Ther Massage Bodywork. 2016; 9: 15-26.

19. Miller A, Presley J. Bereavement massage: Using massagse as a coping mechanism for the grieving process pre and post death of a loved one. CCMTS Res Compet. 2011: 1-18.

20. Taylor AJ. Massage for the grieving. Where love lived first. Massage and bodywork [Internet]. 2017 [cited $2019 \quad 17$ June]. Available from: https://www.abmp.com/textonlymags/article.php?article=1748.

21. Taylor AJ. The Institute for Grief Massage Inc. 201820 December. [cited 2019]. Available from: https://griefmassage.org/blog/2018/12/15/the-grief-massage-philosophy-approach.

22. Taylor AJ. The Institute for Grief Massage INC. 2019 May 23. [cited 2019]. Available from: https://griefmassage.org/blog/communication-skills-grief-massage.

23. Brennan JL. HELD massage therapy. 2018 April 10. [cited 2019]. Available from: http://www.heldmassagetherapy.com/massage-for-times-of-grief-and-stress/.

24. Benson H, Beary JF, Carol MP. The relaxation response. Psychiatry. 1974; 37: 37.

25. Edwards DJ, Young $H$, Johnston R. The immediate effect of therapeutic touch and deep touch pressure on range of motion, interoceptive accuracy and heart rate variability: A randomized controlled trial with moderation analysis. Front Integr Neurosci. 2018; 12: 41-41.

26. Diego MA, Field T. Moderate pressure massage elicits a parasympathetic nervous system response. Int J Neurosci. 2009; 119: 630-638.

27. Field T. Touch for socioemotional and physical well-being: A review. Development Rev. 2010; 30: 367-383.

28. Ellingsen D-M, Leknes S, Loseth G, Wessberg J, Holasusson H. The neurobiology shaping affective touch: Expectation, motivation, and meaning in the multisensory context. Front Psychol. 2016; 6: 1-16.

29. Gentry JW, Kennedy PF, Paul K, Hill RP. The vulnerability of those grieving the death of a loved one: implications for public policy. J Public Policy Mark. 1995; 14: 128-142.

30. Harris H, Lee C, Yancey G. Cognition in Adult Bereavement: Preliminary Findings From Five Hospice Bereavement Focus Groups. J Soc Work End Life Palliat Care. 2015; 11: 283-306.

31. Bellhouse $C$, Temple-Smith M, Watson S, Bilardi J. The loss was traumatic... some healthcare providers added to that: Women's experiences of miscarriage. J Aust Coll Midwives. 2019; 32: 137-146. 


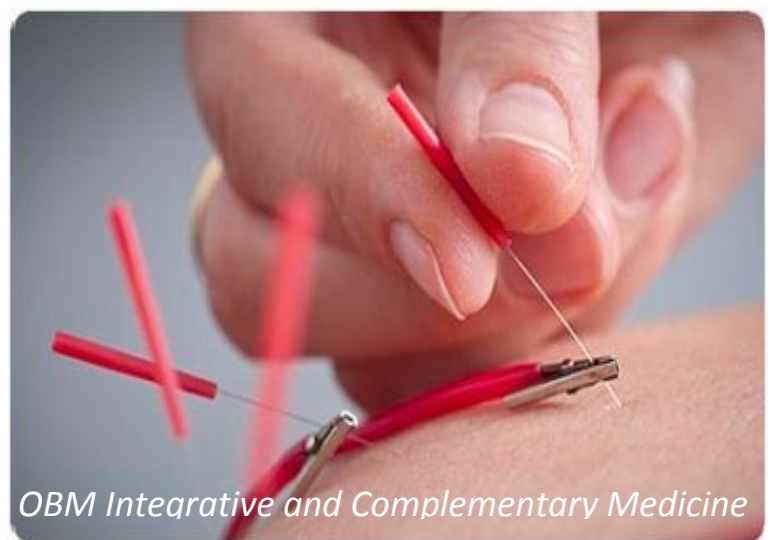

Enjoy OBM Integrative and Complementary Medicine by:

1. Submitting a manuscript

2. Joining in volunteer reviewer bank

3. Joining Editorial Board

4. Guest editing a special issue

For more details, please visit: http://www.lidsen.com/journals/icm 